Journal of History Culture and Art Research (ISSN: 2147-0626)

Tarih Kültür ve Sanat Araştırmaları Dergisi

Vol. 9, No. 4, December 2020

\title{
DOI: 10.7596/taksad.v9i4.2425
}

Citation: Erbaş, S., \& Aksoy, B. (2020). Sosyal Bilgiler Öğretmen Adaylarının Millî Kimlik Algılarının Incelenmesi.Journal of History Culture and Art Research, 9(4), 415-428. doi:http://dx.doi.org/10.7596/taksad.v9i4.2425

\section{Sosyal Bilgiler Öğretmen Adaylarının Millî Kimlik Algılarının İncelenmesi*}

\author{
Social Studies Teacher Candidates' Perceptions of National Identity
}

Sadettin Erbaş ${ }^{1}$, Bülent Aksoy ${ }^{2}$

\begin{abstract}
This study examines the social studies teacher candidates' perceptions of national identity. The research was carried out by using the quantitative method within the scanning model. 536 students in 4 state universities who were studying social studies in different regions of Turkey were reached. In the study, the 5-point likert grading system is used along with a "perception of national identity" scale which consists of 20 items and 2 factors. The analysis of the obtained data was done through the SPSS 22.0 package program. Descriptive statistics such as frequency, percentage and averages were used to analyze the data; $\mathrm{t}$-test, one-way variance analysis and Kuruskal Wallis $\mathrm{H}$ tests were applied. According to the results obtained from the research, it was determined that the social studies teacher candidates' national identity perception levels were high.The national identity perception levels of social studies teacher candidates did not differ significantly according to gender. The national identity perception levels did not differ significantly according to the social-class variable. The national identity perception levels did not differ significantly according to the residential unit variable of where they had lived before university. There was a significant difference in the national identity perception levels of social studies teacher candidates according to the family variable and the institutional variable where the national identity was acquired. The national identity perception levels of social sciences teacher candidates were found to be significantly different based on the elements of history and religion; the most influential factors in the acquisition of national identity. In this research, a quantitative data collection tool was used. Therefore, the existing situation has been identified and tried to be described. Qualitative research is recommended to deal with national identity perception situations in a more detailed and in-depth manner and to determine why and how national identity in individuals is formed.
\end{abstract}

Keywords: Identity, National identity, Social studies education, Teacher candidates.

\footnotetext{
*Bu çalışma birinci yazarın ikinci yazar danışmanlığında hazırlamış olduğu "Sosyal Bilgiler Eğitimi Lisans Öğrencilerinin Millî Kimlik Algılarının İncelenmesi” adlı yüksek lisans tez çalışmasından üretilmiştir.

${ }^{1}$ Doktora Öğrencisi,Gazi Üniversitesi Eğitim Bilimleri Enstitüsü, Sosyal Bilgiler Eğitimi Bilim Dalı, Ankara/Türkiye, e-mail: s.erbas66@gmail.com

${ }^{2}$ Doç. Dr., Gazi Üniversitesi Gazi Eğitim Fakültesi, Sosyal Bilgiler Eğitimi Anabilim Dalı, Ankara/Türkiye, e-mail: baksoy28@gmail.com
} 
Bu araştırmada sosyal bilgiler öğretmen adaylarının millî kimlik algılarının incelenmesi amaçlanmıştır. Araştırma nicel yöntem kullanılarak ve tarama modelinde gerçekleştirilmiştir. Araştırmada çalışma grubu olarak Türkiye'nin farklı bölgelerindeki 4 devlet üniversitesinde eğitim gören 536 sosyal bilgiler öğretmen adayına ulaşılmıştır. Araştırmada 5'li likert dereceleme ölçeği türünde 20 madde ve 2 faktörden oluşan "milli kimlik algısı" ölçeği kullanılmıştır. Elde edilen verilerin analizi SPSS 22.0 paket programı aracılığıyla yapıımıştır._Verilerin çözümlenmesinde frekans, yüzde ve ortalama gibi betimsel istatistikler kullanılmış; t-testi, tek yönlü varyans analizi ve Kuruskal Wallis $\mathrm{H}$ testleri uygulanmıştır. Araştırmadan elde edilen sonuçlara göre sosyal bilgiler öğretmen adaylarının millî kimlik algı düzeylerinin yüksek olduğu tespit edilmiştir. Sosyal bilgiler öğretmen adaylarının millî kimlik algı düzeyleri cinsiyet, sınıf düzeyleri ve üniversite öncesinde yaşadıkları yerleşim birimi değişkenlerine göre anlamlı farklııık göstermemiştir. Sosyal bilgiler öğretmen adaylarının millî kimlik algı düzeylerinde, millî kimliğin kazanıldığı kurum değişkenine göre ve millî kimliğin kazanımı konusunda en etkili unsur değişkenine göre aile değişkenine lehine anlamlı farklılık bulunmuştur. Bu araştırmada milli kimlik algı düzeyi nicel yöntem kullanılarak araştırılmıştır. Dolayısıyla var olan durum betimlenmeye çalışılmıştır. Millî kimlik algı durumlarının daha detaylı ve derinlemesine bir şekilde ele alınması, bireylerdeki millî kimliğin neden, niçin ve nasıl oluştuğunun tespitleri için nitel araştırmalar yapılması önerilmektedir.

Anahtar Kelimeler:_Kimlik, Millî kimlik, Sosyal bilgiler eğitimi, Öğretmen adayı.

\section{Giriş}

Kimlik konusu, sosyal bilimlerin bütün alanlarındaki en karmaşık ve tartışmalı konulardan birisidir. Bu durumun sebebi, kimliğin çok boyutlu olması ve her bir boyutuyla da farklı bir disiplinin ilgilenmesidir (Türkbağ, 2003, s. 209). Kimlik, günümüz dünyasının en popüler kavramlarından birisi olarak; psikoloji gibi bireyle ilgili olanından, sosyoloji, sosyal psikoloji, antropoloji ve siyaset bilimi gibi toplumsal yapıyla ve yaşamla ilgili olanlarına kadar birçok bilimsel disiplinde merkezi konuma sahip olma özelliğini sürdürmeye devam eden bir kavramdır. Kişinin diğer kişilerle ve grubuyla veya grubun diğer gruplarla ilişkilerinden ve toplumsallaşma şartlarından söz edilirken veyahut iki yüzyıldır varlı̆ı̆ın sürdüren adeta katılaşmış homojen ulus-devlet yapılarının gevşemesiyle başta Balkanlar, Ortadoğu ve Kafkaslar olmak üzere dünyanın birçok bölgesinde etnik aidiyet temelinde ortaya çıkan milliyetçiliklerden söz ederken, kimlik daima merkezde yer alan bir kavram olarak karşımıza çıkmakta ve bu özelliğini hâlâ korumaktadır (Vatandaş, 2004, s. 15).

Kimlik kavramı, insanın kendisini nasıl algıladığı ve tanımladığıdır. Dolayısıyla kimlik insanın kendi kendisini kavrayışının bir ifadesidir (Bilgin, 2007, s. 78; Güvenç, 2008, s. 8)._Kimlik, insanları hem tanımlayan hem de kişilerin hayatına yön veren zihinsel bir yapıdır (Chafetz, Spirtas ve Frankel'den aktaran Dağı, 2002, s. 46). "Kimlik, birbirini tamamlayan kişisel ve sosyal süreçlerin eşliğinde kişinin kendisinde meydana gelir" (Doğan, 2008, s. 11). İnsanın kendisinin bilincine varması, bir anda ortaya çıkan ya da miras alınan değişmez bir algılayış ya da kavrayış değil, insanın gelişim süreci boyunca diğerler insanlar ve gruplarla etkileşim içerisinde öğrenilen, geliştirilen bir olgudur (Bilgin, 2007, s. 78). 
Kimlik türleri bireysel ve kolektif kimlikler olarak iki ana başlık altında toplanabilir. Bu çalışmanın konusu gereği sadece kolektif kimlik türlerinden milli kimlik ele alınmıştır.

Millî kimlik, kolektif kimliğin en özgün türlerinden birisi (Bilgin, 1995, s. 60; Morley'den aktaran Vatandaş, 2004, s. 25) ve kolektif kimlik tartışmalarının en hayati bahsinin temerküz ettiği başık olarak alan uzmanlarının ittifak edebileceği bir noktadır (Çalık, 2009, s. 10). Millî bir kimliğin var olabilmesi için; kendilerini millet olarak kabul eden, ortak tarih, coğrafya, dil, kültür ve dine sahip olan bir insan topluluğuna intiyaç vardır.

Bireylerin kimlikleri en geniş anlamlarıyla onların bütün özelliklerinin toplamıdır. Bir insanın doğuştan sahip olduğu özellikler, almış olduğu eğitim, içinde büyüdüğü kültür, ailesi ve çevresinden kazanmış olduğu özelliklerin tamamı $\iota_{L}$ o kişinin kimliğinin esas muhtevasını teşkil etmektedir. Kişilerin sahip olduğu gibi toplumların da bir kimliği bulunmaktadır. Millet toplumlar da bu doğrultuda birer millî kimliğe sahiptirler (Çeçen, 2007, s. 245).

Millî kimlik, özgün bir kolektif kimlik biçimi olması nedeniyle toplumsal aidiyet duygusunun oluşması ve diğer ortak yönlerin geliştirilmesi yönünde millî topluluğun oluşumunda etkin bir role sahiptir (Şen, 2004, s. 90). Aidiyet ve özdeşleşmenin en bariz görüldüğü kimlik türü millî kimliktir (Sözen, 1999, s. 14). Millet olma sürecini tamamlamış toplumların bireyleri, bir millete aidiyetlerini doğal bir durum olarak içselleştirir ve bu topluluğa karşı duyulan yükümlülüğü sorumluluk derecelendirmesinde üst sıralara yerleştirirler (Köktürk, 2016, s. 35). Bu aidiyet ve benimseme duygusu milletlerin yaşaması ve devamı için oldukça önemlidir. İbni Haldun’a göre bir millet “kimliğini” temsil eden aidiyet duygusunu yitirdiği zaman tarih sahnesinden silinir gider (Türkdoğan, 2007, s. 20).

Millî kimlik ulusal bir grubu ötekinden, bir takım millî özellikler tanımlayarak ve o özellikler üzerinden diğer bütün ötekilerle arasında bir sınır çizerek ayırır. Bu ayırıcı özellikler çeşitli amaçlara hizmet ederler; bir dayanışma duygusu yaratırlar, toplumların birbirlerinden farklılıklarını ifade etmek, insan gruplarını harekete geçirmek ve kitleleri belirli toplumsal hedeflere konsolide etmek üzere kullanılması (Bowman'dan aktaran Tabur, 2014, s. 25). sürecin ideolojik değil, aynı zamanda psikolojik_olduğunun da kanıtıdır (Tolimson'dan aktaran Tekinalp, 2005, s. 77).

Devletlerin ve milletlerin millî ülkülerine uygun olarak yetiştirdiği insanlar, bir milletin ilerlemesini ve kalkınmasını sağlayan en önemi kaynağıdır. Fertlerini çağın şartlarına en uygun şekilde yetiştiremeyen milletlerin varlıklarını idame ve muhafaza etmeleri imkânsızdır. Bu sebeple eğitim; milletlerin bir bütün olarak ele almak, iyi organize etmek mecburiyetinde oldukları bir alandır. Her ülkedeki eğitim sistemi, o ülkenin içtimai, iktisadi ve kültürel yapısı ile uygun biçimde oluşturulmalıdır (Çavdarcı, 2002, s. 96).

Bireyin biyolojik bir varlık olmaktan öteye geçip toplumsal bir varlık haline gelmesi, onun içinde yaşadığı toplumun değerlerini ve normlarını öğrenip toplumsal kültürü içselleştirerek bir kimlik geliştirdiği ölçüde mümkündür. Bu durum eğitim ve sosyalleşme süreçlerinde, bireylerin mensup oldukları toplumla kurdukları sosyal etkileşimler ve topluma ait değerleri benimsemeleriyle somutlaşmaktadır. Bireylerin kimlik gelişiminde mensup oldukları topluma karşı geliştirdikleri aidiyet duygusu, aynı zamanda toplumsal birliğin ve bütünlüğün sağlanması ve süreklilik kazanması açısından oldukça önemlidir (Esgin, 2014, s. 78).

Bireylerin kimlikleri, gelişim dönemlerinde iç ve dış birçok unsurun etkisi ile birlikte oluşur. Bireyin iç dünyasında kimlik oluşumunu psikolojisi ve yaşantılar yoluyla edindiği bilgiler etkiler iken, dış dünyada 
ise bireyi etkileyen unsurlar; aile, okul ve çevredir. Bu dış unsurlar içerisinde bireye bilinçli ve sistematik bir kolektif kimlik kazandırma işlevi olan kurum ise eğitim kurumudur.

Türk millî kimliğinin yeni nesillere benimsetilmesinde millî eğitim önemli görevler üstlenmiştir. Öğrencilere verilecek millete ait bilgi ve değerler, kişinin milletiyle gurur duymasını ve milletine aidiyet hissetmesini sağlayacaktır (Turan, 2009, s. 29). Millî kimlik, millî değerlerin öğretilmesine odaklaşan millî bir eğitim sistemi ile şekillenir ve süreklilik kazanır (Kodaman, 2004, s. 29). Milleti oluşturan bütün bireyler, millî bir eğitim sisteminde yetiştirilerek bir bütünün parçaları olarak toplumsal yaşama dâhil edilirler (Çeçen, 2007, s. 244). Millî kimlik özelliklerinin ne kadar ve ne ölçüde kişiye kazandırılabildiği, eğitim ve sosyalleşme süreçlerinin başarısı ile doğrudan ilgilidir (Kösoğlu, 2015, s. 100).

Şüphesiz sosyal bilgiler dersi de mevcut çok disiplinli ve çok boyutlu yapısı nedeniyle kimlik konusu ile özellikle de 11-14 yaş arası ortaokul çocuklarının bireysel ve toplumsal kimlik kazanmasında oldukça önemli bir yere sahiptir. Türkiye Cumhuriyeti Devleti gibi üniter devlet yapısına sahip olan ülkelerde de iyi vatandaşın tanımı olarak devletine ve milletine bağlı, ödevlerini yerine getiren hak ve sorumluluklarının bilincinde insan tipi ön plana çıkmaktadır. Devletine ve milletine bağlı, ödevlerini yerine getiren hak ve sorumluluklarının bilincinde insanlar yetiştirmenin en önemli ayaklarından bir tanesi de bireylere erken yaşlardan itibaren eğitim-öğretim yoluyla millî aidiyet, mensubiyet ve şahsiyet duygularının aktarılmasıdır. Bu aidiyet, mensubiyet ve şahsiyetin adı da millî kimliktir. Millî kimlik algısının bireye aktarılması için ortaokul düzeyinde en uygun ders sosyal bilgiler dersleridir. Sosyal bilgiler dersi konuları içerisinde bulunan tarih, coğrafya, vatandaşık, antropoloji gibi disiplinler sayesinde bireylerin genç yaşta millî kimlik kazanmasına birinci derecede katkı sağlayacaktır.

Sosyal bilgiler eğitim programlarının (2005 ve 2018) hedefleri arasında, millî eğitimin genel amaçları ve Türkiye Cumhuriyeti Anayasası'nın öngördüğü şekilde bireylerde millî kimliği temel alan bir dünya görüşü oluşturmak, bu yolla Türkiye Cumhuriyeti vatandaşlarının devletine bağılığını tesis etmek gösterilmektedir. Bu çerçevede en uygun ders ortaokul düzeyinde sosyal bilgiler dersidir. Hatta sosyal bilgiler öğrenme alanları içerisinde yer alan "Birey ve Toplum" öğrenme alanı doğrudan bu amaca hizmet etmek maksadıyla oluşturulmuş ve bireylerde çocukluk çağından itibaren devletine bağlı bir vatandaş yetiştirmeyi hedef almıştır.

Araştırma üniversitelerdeki sosyal bilgiler lisans programının, ortaokullarda okutulan sosyal bilgiler ders programının genel amaçları içerisinde olan milî kimlik aktarımı konusunda öngörülen hedeflere uygun olup olmadığını ve sosyal bilgiler öğretmen adaylarının millî kimlik algı düzeylerine etkisinin belirlenmesine ilişkin veri kaynağı oluşturacak olması ve daha önce alanda bu doğrultuda hiçbir çalışma yapılmamış olması bakımından önemlidir.

\section{Araştırmanın Amacı}

Çalışmanın amacı millî kimlik algısını eğitim-öğretim bağlamında, ortaokul döneminde öğrencilere millî kimlik aktarımı yapmak için en uygun ders olan sosyal bilgiler dersi özelinde, meslek hayatlarında millî kimlik unsurlarını öğrencilere aktaracak olan, üniversitelerde öğrenim gören sosyal bilgiler_öğretmen adaylarının millî kimlik algı düzeylerini belirlemektir.

\section{Problem cümlesi}

Sosyal bilgiler öğretmen adaylarının millî kimlik algıları ne düzeydedir? 


\section{Alt problemler}

1. Sosyal bilgiler öğretmen adaylarının millî kimlik algısı cinsiyetlerine göre farklılaşmakta mıdır?

2. Sosyal bilgiler öğretmen adaylarının millî kimlik algısı sınıf düzeylerine göre farklılaşmakta mıdır?

3. Sosyal bilgiler öğretmen adaylarının millî kimlik algısı üniversite öncesi yaşadıkları yerleşim birimine göre farklılaşmakta mıdır?

4. Sosyal bilgiler öğretmen adaylarının millî kimlik algısı, millî kimlik algısı üzerinde en fazla etkili olan kurum değişkenine göre farklılaşmakta mıdır?

5. Sosyal bilgiler öğretmen adaylarının millî kimlik algısı, millî kimlik oluşumunda en etkili olan unsur değişkenine göre farklılaşmakta mıdır?

6. Sosyal bilgiler öğretmen adaylarının millî kimlik algısı üzerinde en fazla etkili olan unsur, millî kimlik oluşumunda en fazla etkili olan kuruma göre farklılaşmakta mıdır?

\section{YÖNTEM}

Araştırmada nicel araştırma yöntemlerinden tarama modeli kullanılmıştır. Tarama modeli, bir evren içinden seçilen bir örneklem üzerinde yapılan çalışmalar yoluyla evren genelindeki eğilim, tutum veya görüşlerin sayısal olarak betimlenmesini sağlar (Creswell, 2014, s. 155). Tarama modeli, geçmişte ya da halen var olan bir durumu var olduğu şekliyle betimlemeyi amaçlayan araştırma yaklaşımlarıdır. Araştırmaya konu olan olay, birey ya da nesne, kendi koşulları içinde ve olduğu gibi tanımlanmaya çalışılır. Herhangi bir şekilde manipülasyon yapılmaz (Karasar, 2014, s. 77).

\section{Çalışma grubu}

Bu araştırmada amaçlı örnekleme yolu kullanılarak Türkiye'nin farklı illerinde yer alan 4 devlet üniversitesindeki 536 sosyal bilgiler öğretmen adayı çalışma grubu olarak seçilmiştir. Amaçlı örnekleme çalışmanın amacına bağlı olarak bilgi açısından zengin durumların seçilerek derinlemesine araştırma yapılmasına olanak tanır. Belli ölçütleri karşılayan veya belli özelliklere sahip olan bir veya daha fazla özel durumlarda çalışılmak istenildiğinde tercih edilir (Büyüköztürk ve diğerleri, 2012, s. 90).

Tablo 1: Çalışma Grubuna Ait Betimsel Özellikler

\begin{tabular}{|clll|}
\hline & & $F$ & $\%$ \\
\hline \multirow{3}{*}{ Cinsiyet } & Kadın & 302 & 56.3 \\
\cline { 2 - 4 } & Erkek & 234 & 43.7 \\
\cline { 2 - 4 } & Toplam & 536 & 100.0 \\
\hline \multirow{3}{*}{ Sınıf Düzeyi } & 1. Iınıf & 124 & 23.1 \\
\cline { 2 - 4 } & 2. Inıf & 129 & 24.1 \\
\cline { 2 - 4 } & 3.Sınıf & 166 & 31.0 \\
\cline { 2 - 4 } & 4.Sınıf & 117 & 21.8 \\
\cline { 2 - 4 } Yerleşim Birimi & Toplam & 536 & 100.0 \\
\hline & Köy & 94 & 17.5 \\
\cline { 2 - 4 } & Kasaba & 54 & 10.1 \\
\cline { 2 - 4 } & Şehir & 388 & 72.4 \\
\cline { 2 - 4 } & Toplam & 536 & 100.0 \\
\hline
\end{tabular}

Tablo 1'de görüldüğü gibi 536 kişilik çalışma grubunun \% 56.3'ü (302) kadın \% 43.7'si (234) erkektir. Araştırmaya katılan öğrenciler 1. ve 2. sınıflarda birbirine yakın bir dağılım göstermektedir. En düşük 
katılım \%21.8'lik (117) oranla 4. sınıflara ait iken, en yüksek katılım \%31.0'ık (166) oran ile 3. sınıf öğrencilerine aittir. Üniversite öncesinde öğrencilerin \%10.1'i (54) kasabada \%17.5'i (94) köyde ve \%72.4'ü (388) ise şehirde yaşamaktadır.

Tablo 2: Katılımcıların Millî Kimliği Kazandıkları Kurumlara Göre Dağılımı

\begin{tabular}{|ccc|}
\hline Kurum & $\mathrm{f}$ & $\%$ \\
\hline Aile & 335 & 62.5 \\
\hline Okul & 133 & 24.8 \\
\hline Sivil toplum & 36 & 6.7 \\
\hline Yayınlar & 32 & 6.0 \\
\hline Toplam & 536 & 100.0 \\
\hline
\end{tabular}

Tablo 2'ye göre araştırmaya katılan öğrenciler millî kimliklerini \%62.5 (355) ile aileden; \%24.8 (133) ile okuldan; \%6.7 (36) ile sivil toplum kuruluşlarından; \%6.0 (32) ile de okudukları yayınlardan edindiklerini belirtmiştir.

Tablo 3: Katılımcıların Millî Kimliğin Hangi Unsurunu Önemli Gördüklerine Illişkin Dağılım

\begin{tabular}{|ccc|}
\hline Unsur & $\mathrm{f}$ & $\%$ \\
\hline Tarih & 193 & 36.0 \\
\hline Coğrafya & 35 & 6.5 \\
\hline Dil & 61 & 11.4 \\
\hline Kültür & 207 & 38.6 \\
\hline Din & 40 & 7.5 \\
\hline Toplam & 536 & 100.0 \\
\hline
\end{tabular}

Tablo 3'e göre öğrencilerden tarih \%36.0 (193) ve kültür \%38.6 (207) unsurlarının önemli olduğunu söyleyenler birbirine yakın dağılım göstermiştir. Yine öğrencilerden coğrafya \%6.5 (35) ve din \%7.5 (40) unsurlarının önemli olduğunu söyleyenler birbirine yakın dağıım göstermiştir. Dil unsurunun önemli olduğunu söyleyenler ise \%11.4 (61)'tir.

\section{Veri toplama araçları}

Araştırmada, veri toplama aracı olarak; kişisel bilgi formu ve Gelişli (2014) tarafından 20 madde ve 2 faktörlü $5^{\prime} l i$ likert dereceleme tipinde geliştirilen "Millî Kimlik Algı Ölçeği” kullanılmıştır. Ölçeğin faktör analizinde kullanılan KMO değerinin 0.92 olduğu, Barlett testi sonucunun ise 3123.334 olduğu belirtilmiştir. Yapılan varyans analizinde ölçeğin tamamının toplam varyansı açıklama oranı \%52.30 olarak hesaplanmıştır. Ölçeğin 1. boyutunun açıkladığı varyans \%37.19 iken 2. Boyutunun açıkladığı varyans ise \%15.10 olarak tespit edilmiştir. Ölçeğin tamamı için Cronbach Alpha güvenilirlik katsayısının 0.93 olduğu, 1. Faktöre ait Cronbach Alpha değerinin 0.93 2 2. Faktöre ait Cronbach Alpha güvenilirlik katsayısının ise 0.80 olduğu tespit edilmiştir. Elde edilen bu değerlerden Ölçeğin yüksek güvenilirliğe sahip olduğu tespit edilmiştir. Bu sonuçlara göre ölçeğin yüksek geçerlik ve güvenirliğe sahip olduğu görülmektedir. Ölçeğin 1. boyutu (millî kimlik ve değerler), 2. boyutu (millî kimlik-din) olarak adlandırılmıştır.

\section{Verilerin analizi}

Araştırmadan elde edilen verilerin analizi SPSS 22.0 (Statistical Package for Social Science for Personal Computers) programı kullanılarak yapılmıştır. Frekans, yüzde ve ortalama gibi betimsel istatistikler kullanılmıştır. İlişkisiz örneklemler için t-Testi; illişkisiz Örneklemler için Tek Yönlü Varyans Analizi (ANOVA) ve varyansların homojen olmadığı örneklemde ilişkisiz Örneklem için Kruskal Wallis H testleri uygulanmıştır. 


\section{BULGULAR VE YORUM}

\section{Araştırma Problemine iliş̧kin Bulgular ve Yorum}

Araştırmanın alt probleminde sosyal bilgiler öğretmen adaylarının millî kimlik algı düzeylerinin nasıl olduğunu_belirlemek için "Millî Kimlik Algı Ölçeği” kullanılmıştır. Betimsel analiz sonuçlarına göre sosyal bilgiler öğretmen adaylarının millî kimlik algı düzeyleri tablo 4'te verilmiştir.

Tablo 4: Sosyal Bilgiler Öğretmen Adaylarının Milli Kimlik Algılarına iliş̧kin Betimsel Istatistikler

\begin{tabular}{|lrrr|}
\hline & $\mathrm{N}$ & $\mathrm{X}$ & $\mathrm{S}$ \\
\hline Milli kimlik ve din & 536 & 3.97 & .95 \\
\hline Milli kimlik ve değerler & 536 & 4.47 & .54 \\
\hline
\end{tabular}

Tablo 4 incelendiğinde ölçeğin "millî kimlik ve değerler" boyutunda katılımcıların aritmetik ortalaması ( $\bar{x}=4.47$ )_olduğu görülmektedir. Bu bulgu "millî kimlik ve değerler" boyutunda katılımcıların millî kimlik algı düzeylerinin oldukça yüksek olduğu şeklinde yorumlanabilir. Ölçeğin "millî kimlik ve din" boyutunda ise katılımcıların aritmetik ortalaması ( $\bar{x}=3.97)$ olduğu görülmektedir. Bu bulgu "millî kimlik ve din" boyutunda katılımcıların millî kimlik algı düzeylerinin kısmen yüksek olduğu şeklinde yorumlanabilir.

\section{Birinci Alt Probleme İlişkin Bulgular ve Yorum}

Araştırmanın birinci alt probleminin analizinde sosyal bilgiler öğretmen adaylarının millî kimlik algı ölçeği puanlarının cinsiyete göre farklılaşıp farklılaşmadığı araştırılmıştır. Analiz sonuçları tablo 5'da verilmektedir.

Tablo 5: Sosyal Bilgiler Öğretmen Adaylarının Millî Kimlik Algısı Ölçeği Puanlarının Cinsiyete Göre Farklılığı lç̧in t-Testi Sonuçları

\begin{tabular}{|lcccccccc|}
\hline Boyut & Grup & $\mathbf{N}$ & $\bar{x}$ & $\mathbf{S}$ & sd & t & $\mathbf{P}$ \\
\hline Millî kimlik ve değerler & Kadın & 302 & 4.46 & .54 & & & \\
& Erkek & 234 & 4.47 & .53 & & 534 & -0.52 & .622 \\
\hline Millî kimlik ve din & Kadın & 302 & 3.91 & .95 & & & \\
\cline { 2 - 6 } & Erkek & 234 & 4.05 & .93 & 534 & -1.601 & .979 \\
\hline
\end{tabular}

Ölçeğin 1. boyutuna ilişkin t-testi sonuçlarına göre; cinsiyete göre "millî kimlik ve değerler" boyutunda anlamlı bir farklılık bulunmamıştır $\left(t_{(534)}=-0.52, p>.05\right)$. Bu verilere göre Millî kimlik ve değerler boyutunda kız öğrencilerin puanlarının ortalaması $(\bar{x}=4.46)$, erkek öğrencilerin puanlarının ortalaması ise $(\bar{x}=4.47)$ olarak gerçekleşmiştir. Bu bulgu millî kimlik ve değerler boyutunda sosyal bilgiler öğretmen adaylarının millî kimlik algılarının cinsiyete göre benzer bulunduğu şeklinde yorumlanabilir.

Ölçeğin 2. boyutuna ilişkin t-testi sonuçlarına göre; cinsiyete göre "millî kimlik ve din" boyutunda anlamlı bir farklılık bulunmamıştır $\left(\mathrm{t}_{(534)}=-1.601, \mathrm{P}>.05\right)$. Tablodaki verilere göre millî kimlik ve din boyutunda kız öğrencilerin puanlarının ortalaması $(\bar{x}=3.92)$ erkek öğrencilerin puanlarının ortalaması ise $(\bar{x}=4.05)$ olarak gerçekleşmiştir. Bu bulgulara göre millî kimlik ve din boyutunda sosyal bilgiler öğretmen adaylarınınmillî kimlik algılarını cinsiyete göre benzer bulunmuştur.

\section{ìkinci Alt Probleme ilişkin Bulgular ve Yorum}

Araştırmanın ikinci alt probleminin analizinde sosyal bilgiler öğretmen adaylarınınmillî kimlik algı ölçeği puanlarının sınıf düzeyine göre farklılaşıp farklılaşmadığı araştırılmıştır. Analiz sonuçları tablo $6^{\prime} \mathrm{da}$ verilmektedir. 
Tablo 6: Sosyal Bilgiler Öğretmen Adaylarının Millî Kimlik Algısı Ölçeği Puanlarının Sınıf Düzeyine Göre Farklılığı lçin Betimsel Istatistikler ve Tek Yönlü Varyans Analizi

\begin{tabular}{|c|c|c|c|c|c|c|c|c|c|}
\hline Sinıf & Boyut & $\mathrm{N}$ & $\bar{X}$ & $S$ & Boyut & \multicolumn{2}{|c|}{$\mathrm{N}$} & $\bar{X}$ & $\mathrm{~S}$ \\
\hline 1.sınıf & \multirow{4}{*}{$\begin{array}{l}\text { Millî } \\
\text { kimlik } \\
\text { ve } \\
\text { değerler }\end{array}$} & 124 & 4.45 & .47 & \multirow{4}{*}{$\begin{array}{l}\text { Millî kimlik } \\
\text { ve din }\end{array}$} & \multicolumn{2}{|c|}{124} & 3.95 & .97 \\
\hline 2.sinif & & 129 & 4.41 & .55 & & \multicolumn{2}{|c|}{129} & 3.87 & .93 \\
\hline 3.sinif & & 166 & 4.49 & .55 & & \multicolumn{2}{|c|}{166} & 4.01 & .98 \\
\hline 4.sinif & & 117 & 4.51 & .57 & & \multicolumn{2}{|c|}{117} & 4.05 & .88 \\
\hline & & \multicolumn{2}{|c|}{$\begin{array}{l}\text { Varyansın } \\
\text { Kaynağı }\end{array}$} & & KT & Sd & KO & $\mathrm{F}$ & $p$ \\
\hline \multirow{3}{*}{$\begin{array}{l}\text { Millî kimlik } \\
\text { ve değerler }\end{array}$} & & \multicolumn{2}{|c|}{ Gruplar arası } & & .786 & 3 & .26 & \multirow{3}{*}{.907} & \multirow{3}{*}{.437} \\
\hline & & \multicolumn{2}{|c|}{ Gruplar içi } & & 153.65 & 532 & \multirow[t]{2}{*}{.29} & & \\
\hline & & Top & & & 154.44 & 535 & & & \\
\hline \multirow{3}{*}{$\begin{array}{l}\text { Millî kimlik } \\
\text { ve din }\end{array}$} & & \multicolumn{2}{|c|}{ Gruplar arası } & & 2.36 & 3 & .79 & \multirow{3}{*}{.879} & \multirow{3}{*}{.452} \\
\hline & & \multicolumn{2}{|c|}{ Gruplar içi } & & 476.86 & 532 & .90 & & \\
\hline & & \multicolumn{2}{|c|}{ Toplam } & & 479.23 & 535 & & & \\
\hline
\end{tabular}

Analiz sonucunda millî kimlik algısı ölçeği alt boyutlarından; sosyal bilgiler öğretmen adaylarının millî kimlik ve değerler boyutu puanları sınıf düzeyine göre anlamlı bir farklııı göstermemiştir $\left[\mathrm{F}_{(3-532)}=.907\right.$; p>.05]. Sosyal bilgiler öğretmen adaylarının millî kimlik ve din boyutu puanları sınıf düzeyine göre anlamlı bir farklılık göstermemiştir $\left[\mathrm{F}_{(3-532)}=.879 ; \mathrm{p}>.05\right]$. Bu bulgular katılımcıların millî kimlik algı düzeylerinin sınıf düzeyine göre benzer bulunduğu şeklinde yorumlanabilir.

\section{Üçüncü Alt Probleme ilişkin Bulgular ve Yorum}

Araştırmanın üçüncü alt probleminin analizinde sosyal bilgiler öğretmen adaylarının millî kimlik algı ölçeği puanlarının üniversite öncesinde yaşadıkları yerleşim birimine göre farklılaşıp farklılaşmadığı araştırılmıştır. Analiz sonuçları tablo 8'de verilmektedir.

Tablo 8: Sosyal Bilgiler Öğretmen Adaylarının Millî Kimlik Algısı Ölçeği Puanlarının Üniversite Öncesi Yaşadıkları Yerleşim Birimine Göre Farklılığı İçin Betimsel Istatistikler ve Tek Yönlü Varyans Analizi

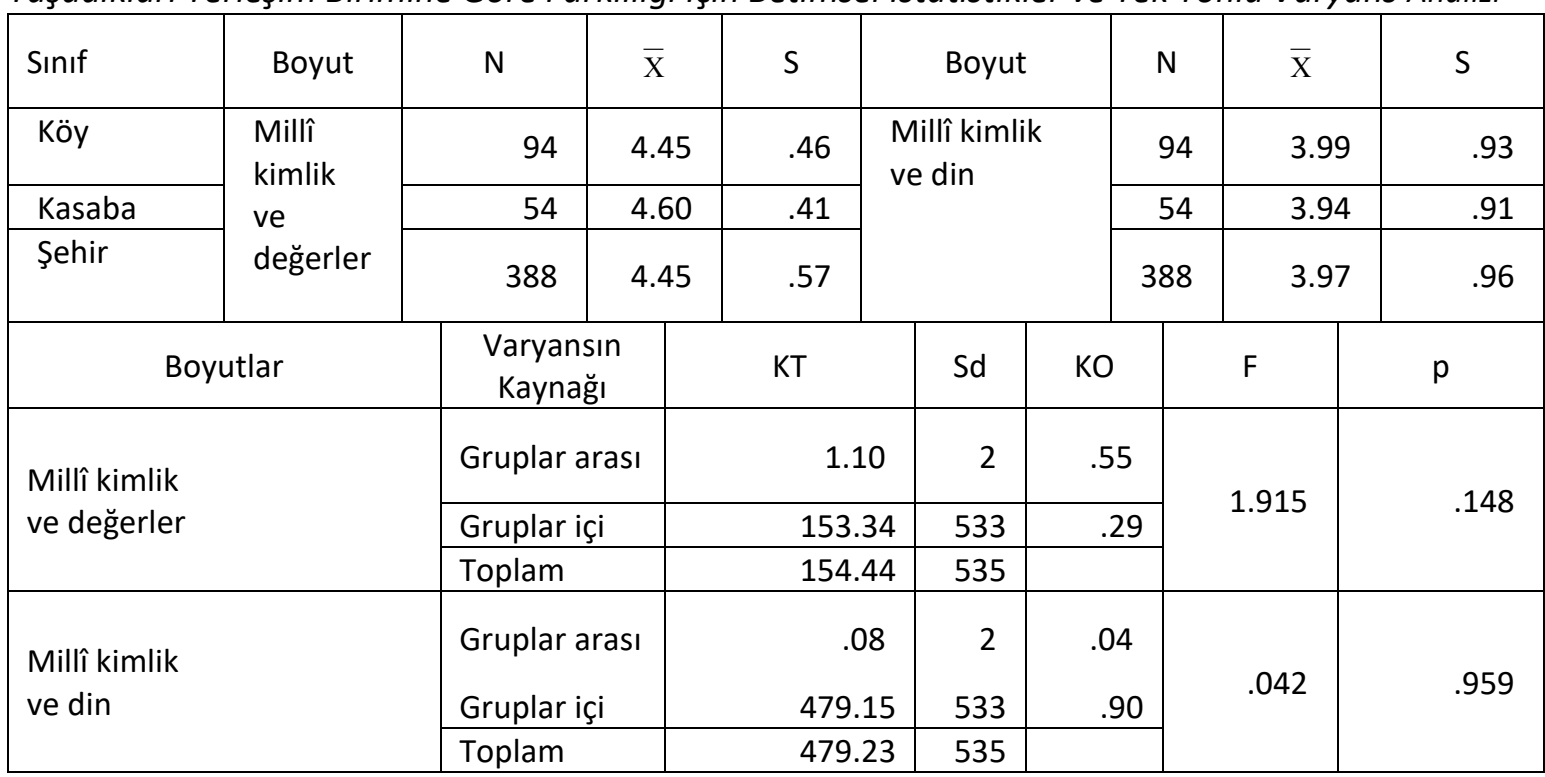


Analiz sonucunda millî kimlik algısı ölçeği alt boyutlarından;

Sosyal bilgiler öğretmen adaylarının millî kimlik ve değerler boyutu puanları üniversite öncesinde yaşadıkları yerleşim birimine göre anlamlı bir farklıık göstermemiştir $\left[F_{(2-533)}=1,915 ; p>.05\right]$.

Sosyal bilgiler öğretmen adaylarının millî kimlik ve din boyutu puanları üniversite öncesinde yaşadıkları yerleşim birimine göre anlamlı bir farklılık göstermemiştir $\left[\mathrm{F}_{(2-533)}=, 042 ; \mathrm{p}>.05\right]$.

Bu bulgu katılımcıların üniversite öncesi yaşadıkları yerleşim birimlerinin millî kimlik algısı üzerinde benzer etkiye sahip olduğunu göstermektedir.

\section{Dördüncü Alt Probleme ilişkin Bulgular ve Yorum}

Araştırmanın dördüncü alt probleminin analizinde sosyal bilgiler öğretmen adaylarının millî kimlik algı ölçeği puanlarının millî değerleri en fazla edindikleri kuruma göre farklılaşıp farklılaşmadığı araştırılmıştır. Analiz sonuçları tablo 10 'da verilmektedir.

Tablo 10: Sosyal Bilgiler Öğretmen Adaylarının Millî Kimlik Algısı Ölçeği Puanlarının Millî Değerleri En Fazla Hangi Kurumdan Edindiklerine Göre Farklıı̆̆ı İ̧in Betimsel Istatistikler ve Tek Yönlü Varyans Analizi

\begin{tabular}{|c|c|c|c|c|c|c|c|c|c|}
\hline Sinif & Boyut & $\mathrm{N}$ & $\overline{\mathrm{X}}$ & $S$ & \multicolumn{2}{|c|}{ Boyut } & $\mathrm{N}$ & $\overline{\mathrm{X}}$ & $S$ \\
\hline Aile & Millî & 335 & 4.48 & .51 & \multirow{4}{*}{$\begin{array}{l}\text { Millî } \\
\text { kimlik } \\
\text { ve din }\end{array}$} & & 335 & 4.02 & .92 \\
\hline Okul & ve & 133 & 4.49 & .50 & & & 133 & 3.95 & .94 \\
\hline $\begin{array}{l}\text { Sivil } \\
\text { toplum }\end{array}$ & değerler & 36 & 4.40 & .64 & & & 36 & 3.97 & .87 \\
\hline Yayınlar & & 32 & 4.24 & .81 & & & 32 & 3.52 & 1.24 \\
\hline & & & $\begin{array}{c}\text { Varyansın } \\
\text { Kaynağı }\end{array}$ & & KT & Sd & KO & $\mathrm{F}$ & $\mathrm{p}$ \\
\hline \multirow{3}{*}{\multicolumn{2}{|c|}{$\begin{array}{l}\text { Millî kimlik } \\
\text { ve değerler }\end{array}$}} & & Gruplar arası & & 2.05 & 3 & .68 & \multirow{3}{*}{2.386} & \multirow{3}{*}{.068} \\
\hline & & & Gruplar içi & & 152.39 & 532 & .29 & & \\
\hline & & & Toplam & & 154.44 & 535 & & & \\
\hline \multirow{3}{*}{\multicolumn{2}{|c|}{$\begin{array}{l}\text { Millî kimlik } \\
\text { ve din }\end{array}$}} & & Gruplar arası & & 7.23 & 3 & 2.41 & \multirow{3}{*}{2.716} & \multirow{3}{*}{.044} \\
\hline & & & Gruplar içi & & 472.00 & 532 & .89 & & \\
\hline & & & Toplam & & 479.23 & 535 & & & \\
\hline
\end{tabular}

Analiz sonucunda millî kimlik algısı ölçeği alt boyutlarından;

Sosyal bilgiler öğretmen adaylarının millî kimlik ve değerler boyutu puanları millî kimliği kazandıkları kurumlara göre anlamlı bir farklılık göstermemiştir $\left[\mathrm{F}_{(3-532)}=2.386 ; p>.05\right]$.

Sosyal bilgiler öğretmen adaylarının millî kimlik ve din alt boyutu puanları millî kimliği kazandıkları kurumlara göre anlamlı bir farklılık göstermiştir $\left[F_{(3-532)}=2.716 ; p<.05\right]$. Anlamlı farklııkların hangi gruplar arasında olduğunu belirlemek amacıyla Tukey HSD çoklu karşılaştırma testi yapılmıştır. Tukey HSD testi sonuçlarına göre millî kimlik ve din boyutunda millî kimlik algısının aile $(\bar{x}=4.02)$ ile yayınlardan $(\bar{x}=3.52)$ kazandığını belirten katılımcılar arasında millî kimliği aileden kazananlar lehine anlamlı farklılık vardır. Bu bulgu ailenin millî kimlik oluşumunda yayınlardan daha etkili olduğu şeklinde yorumlanabilir. 


\section{Beşinci Alt Probleme ilişkin Bulgular ve Yorum}

Araştırmanın beşinci alt probleminin analizinde sosyal bilgiler öğretmen adaylarının millî kimlik algı ölçeği puanlarının millî kimliği kazanım unsurlarına göre farklılaşıp farklılaşmadığı araştırılmıştır. Analiz sonuçları tablo $12^{\prime}$ da verilmektedir.

Tablo 12: Katılımcıların Millî Kimlik Algısına ilişsin Görüşlerinin Millî Kimliği Kazanım Unsuru Değişkenine Göre Farklılığı İçin Kruskal Wallis H Testi Sonuçları

\begin{tabular}{|c|c|c|c|c|c|c|c|}
\hline \multirow[b]{2}{*}{ Boyut } & \multirow[b]{2}{*}{ Sira } & \multirow[b]{2}{*}{ Unsur } & \multicolumn{2}{|r|}{ Sira } & \multicolumn{3}{|c|}{ Anlamlı } \\
\hline & & & $\mathbf{N}$ & ort. & $x^{2}$ & $\mathbf{p}$ & Fark \\
\hline \multirow[t]{6}{*}{ Millî kimlik ve değerler } & 1 & Dil & 61 & 279.84 & \multirow[t]{6}{*}{16.483} & \multirow[t]{6}{*}{.002} & \multirow{6}{*}{$\begin{array}{l}2-3 \\
2-4 \\
2-5\end{array}$} \\
\hline & 2 & Tarih & 193 & 300.42 & & & \\
\hline & 3 & $\begin{array}{l}\text { Coğrafy } \\
\text { a }\end{array}$ & 35 & 221.10 & & & \\
\hline & 4 & Kültür & 207 & 247.82 & & & \\
\hline & 5 & Din & 40 & 245.70 & & & \\
\hline & & Toplam & 536 & & & & \\
\hline \multirow[t]{6}{*}{ Millî kimlik ve din } & 1 & Dil & 61 & 281.53 & \multirow[t]{6}{*}{26.224} & \multirow[t]{5}{*}{.000} & \multirow{5}{*}{$\begin{array}{l}1-5 \\
2-5 \\
3-5 \\
4-5\end{array}$} \\
\hline & 2 & Tarih & 193 & 270.82 & & & \\
\hline & 3 & $\begin{array}{l}\text { Coğrafy } \\
\text { a }\end{array}$ & 35 & 241.61 & & & \\
\hline & 4 & Kültür & 207 & 246.00 & & & \\
\hline & 5 & Din & 40 & 377.39 & & & \\
\hline & & Toplam & 536 & & & & \\
\hline
\end{tabular}

Tablo 12 'de yer alan Kruskal Walilis $\mathrm{H}$ testi analiz sonuçlarına göre katılımcıların millî kimlik algısı ölçeğinin millî kimlik ve değerler boyutunda en etkili unsur değişkenine göre anlamlı farklılık görülmektedir $\left[\mathrm{x}^{2}(4)=16.483 ; \mathrm{p}<.05\right]$. Anlamlı farklılıkların hangi gruplar arasında olduğunu belirlemek amacıyla yapılan Man Whitney $U$ testi sonuçlarına göre; Millî kimliğin oluşumunda tarih unsurunun etkili olduğunu belirten katılımcıların sıra ortalamaları (sıra ort=300.42) ile millî kimliğin coğrafya (sıra ort=221.10); kültür (sıra ort=247.82); din (sıra ort $=245.70$ ) unsurlarının etkili olduğunu belirten katılımcılar arasında millî kimliğin oluşumunda tarih unsurunun etkili olduğunu belirtenler lehine anlamlı farklılıklar bulunmuştur.

Kruskal Walilis $\mathrm{H}$ testi analiz sonuçlarına göre katılımcıların millî kimlik algısı ölçeğinin millî kimlik ve din boyutunda millî kimliğin oluşturan en önemli unsur değişkenine göre anlamlı farklılık göstermiştir $\left[\mathrm{x}^{2}(4)=\right.$ 26.224; $p<.05]$. Anlamlı farklılıkların hangi gruplar arasında olduğunu belirlemek amacıyla yapılan Man Whitney $U$ testi sonuçlarına göre; millî kimliğin oluşumunda din unsurunun etkili olduğunu belirten katılımcıların sıra ortalamaları (sıra ort=377.39) ile millî kimliğin dil (sıra ort=281.53); tarih (sıra ort=270.82); coğrafya (sıra or=241.61); kültür (sıra ort=246.00) unsurlarının etkili olduğunu belirten katılımcılar arasında millî kimliğin oluşumunda din unsurunun etkili olduğunu belirtenler lehine anlamlı farklılıklar bulunmuştur.

\section{Altıncı Alt Probleme ilişkin Bulgular ve Yorum}

Araştırmanın altıncı alt probleminin analizinde sosyal bilgiler öğretmen adaylarının millî kimlik algısı üzerinde en fazla etkili olan unsur ve millî kimlik oluşumunda en fazla etkili olan kurum karşılaştırması yapılmıştır. Analiz sonuçları tablo 13 'de verilmiştir. 
Tablo 13: Sosyal Bilgiler Öğretmen Adaylarının Millî Kimlik Algısı Üzerinde En Fazla Etkili Olan Unsur, Millî Kimlik Oluşumunda En Fazla Etkili Olan Kurum Karşılaştırmasına Illişkin Çapraz Tablo

\begin{tabular}{|c|c|c|c|c|c|c|c|}
\hline & & & Aile & Okul & Sivil Toplum & Yayınlar & Toplam \\
\hline \multirow{10}{*}{ Unsur } & \multirow[t]{2}{*}{ Dil } & $\mathrm{N}$ & 39 & 11 & 6 & 5 & 61 \\
\hline & & $\%$ & 63.9 & 18.0 & 9.8 & 8.2 & 100.0 \\
\hline & \multirow[t]{2}{*}{ Tarih } & $\mathrm{N}$ & 100 & 71 & 8 & 14 & 193 \\
\hline & & $\%$ & 51.8 & 36.8 & 4.1 & 7.3 & 100.0 \\
\hline & \multirow[t]{2}{*}{ Coğrafya } & $\mathrm{N}$ & 21 & 6 & 7 & 1 & 3 \\
\hline & & $\%$ & 60.0 & 17.1 & 20.0 & 2.9 & 100.0 \\
\hline & \multirow[t]{2}{*}{ Kültür } & $\mathrm{N}$ & 146 & 38 & 13 & 10 & 20 \\
\hline & & $\%$ & 70.5 & 18.4 & 6.3 & 4.8 & 10.0 \\
\hline & \multirow[t]{2}{*}{ Din } & $\mathrm{N}$ & 29 & 7 & 2 & 2 & 40 \\
\hline & & $\%$ & 72.5 & 17.5 & 5.0 & 5.0 & 100.0 \\
\hline \multirow[t]{2}{*}{ Toplam } & & $\mathrm{N}$ & 335 & 133 & 36 & 32 & 536 \\
\hline & & $\%$ & 62.5 & 24.8 & 6.7 & 6.0 & 10.0 \\
\hline
\end{tabular}

Not: Beklenen frekans değeri 5'in altında gözenek sayısı (6) toplam gözenek sayısının \%20'sini aştığı (\%30) için ki-kare istatistik değeri yorumlanamamıştır.

Sosyal bilgiler öğretmen adaylarındanmillî kimlik algısı üzerinde en fazla etkili olan unsur nedir sorusuna cevap verenlerin; \%38.6'i Kültür; \%36'sı Tarih; \%11.4'ü Dil; \%7.5'i Din ve \%6.5'i ise Coğrafya olduğu cevabını vermişlerdir. Bu sonuç milli kimliğin oluşumunda en etkili unsurun kültür olduğunu göstermektedir. Katılımcıların milli kimliğin oluşumunda en fazla etkili olan kurum sorusuna ise $\% 62.5^{\prime} i$ aile $\% 24.8^{\prime}$ i okul \%6.7'si sivil toplum kuruluşları ve \%6.0'sı ise yayınlardan cevaplarını vermişlerdir. Bu sonuçlar milli kimlik kazanımında ailenin en etkili kurum olduğunu ortaya koymaktadır.

\section{SONUÇ VE TARTIŞMA}

Araştırmadan elde edilen bulgulara dayanarak ulaşılan sonuçlardan bir tanesi sosyal bilgiler öğretmen adaylarının millî kimlik algı düzeylerinin "millî kimlik ve değerler" $(\bar{x}=4.47)$ boyutunda "tamamen katılıyorum" ve "millî kimlik ve din" ( $\bar{x}=3.97)$ "katılıyorum" boyutlarının her ikisinde de yüksek olduğu tespit edilmiştir. Araştırma sonuçlarına göre, sosyal bilgiler öğretmen adaylarının millî kimlik algı ölçeği puanları gerek "millî kimlik ve değerler" gerekse "millî kimlik ve din" boyutunda cinsiyete göre benzer bulunmuştur. Bu sonuç Cihad (2019) tarafından yapılan araştırmanın bulguları ile benzerlik göstermektedir.

Sosyal bilgiler öğretmen adaylarının millî kimlik algı ölçeği puanlarının sınıf düzeyine göre farklılaşıp farklılaşmadığı incelendiğinde katıımcıların millî kimlik algı ölçeği puanları her iki boyutta da (milli kimlik ve değerler, milli kimlik ve din) sınıf düzeyine göre benzer bulunmuştur. Bu alt probleme ilişkin sonuçlar Cihad (2019)' un yaptığı çalışma ile karşılaştırıldığında "milli kimlik ve değerler" alt boyutunda farklılı; "milli kimlik ve din" boyutunda ise benzerlik olduğu görülmektedir.

Araştırma sonuçları, sosyal bilgiler öğretmen adaylarının milli kimlik algı ölçeği "millî kimlik ve değerler" ve "millî kimlik ve din" boyutlarına ilişkin görüşleri üzerinde, üniversite öncesi yaşadıkları yerleşim biriminin benzer etkiye sahip olduğunu göstermektedir. Bu alt probleme ilişkin sonuçlar Cihad (2019)'un yaptığı çalışma ile farklılık göstermektedir. Cihad çalışmasında milli kimlik algısının yaşanılan şehire göre farklılık gösterdiği sonucuna ulaşmıştır.

Sosyal bilgiler öğretmen adaylarının millî kimlik algı ölçeği puanları "millî kimlik ve değerler" boyutunda, millî değerleri en fazla edindikleri kuruma göre farklılaşmamıştır. Buna karşılık, sosyal bilgiler öğretmen adaylarının millî kimlik algı ölçeği puanları "millî kimlik ve din" boyutunda millî kimliği kazandıkları kuruma göre anlamlı bir farklılık göstermiş̧ir. Çoklu karşılaştırma testi sonucunda "millî 
kimlik ve din" boyutunda millî kimlik algısını aileden $(\bar{x}=4.02)$ kazandığını belirten katılımcılar ile yayınlardan ( $\bar{x}=3.52$ ) kazandığını belirten katılımcılar arasında millî kimliği aileden kazananlar lehine anlamlı farklılık bulunmuştur. Bu sonuç, ailenin millî kimlik oluşumunda yayınlardan daha etkili olduğunu göstermektedir.

Sosyal bilgiler öğretmen adaylarının millî kimlik algı ölçeği puanları "millî kimlik ve değerler" boyutunda millî kimliğin oluşmasında en etkili unsur değişkenine göre anlamlı bir şekilde değişiklik göstermektedir. Çoklu karşılaştırma testi sonuçlarına göre; Millî kimliğin oluşumunda tarih unsurunun etkili olduğunu belirten katılımcıların görüşleri sıra ortalaması ile millî kimliğin kazanılmasında coğrafya, kültür, din unsurlarının etkili olduğunu belirten katılımcıların görüşleri arasında millî kimliğin oluşumunda tarih unsurunun etkili olduğunu belirtenler lehine anlamlı farklılıklar bulunmuştur. Katılımcıların millî kimlik algı puanları "millî kimlik ve din" boyutunda da milli kimliği kazanım unsuru değişkenine göre anlamlı farklııı göstermiştir. Çoklu karşılaştırma testi sonuçlarına göre; millî kimliğin oluşumunda din unsurunun etkili olduğunu belirten katılımcıların sıra ortalamaları ile millî kimliğin dil, tarih, coğrafya ve kültür unsurlarının etkili olduğunu belirten katılımcılar arasında millî kimliğin oluşumunda din unsurunun etkili olduğunu belirtenler lehine anlamlı farklılıklar bulunmuştur. Bu sonuçlar; millî kimliğin oluşumunda tarih ve din unsurlarının diğer unsurlardan daha etkili olduğunu göstermektedir. Bu sonuç Cihad (2019)'un Türkmen ortaokul öğrencilerinin milli kimlik algılarını incelediği çalışması ile farklılık göstermektedir. Cihad araştırmasında milli kimlik için en önemli unsurun "vatanperverlik" olduğu sonucuna ulaşmıştır.

Bu sonuç, her milletin tarihe dayalı bir çekirdek kimliği vardır (Kodaman, 2004, s. 29). Tarih öğrencilerde milli kimlik bilincinin gelişmesine olumlu etki etmektedir (Güneş, 2017, s. 1). Tarih bir milletin milli karakter kazanmasında etkin rol oynayan temel bilimlerin başında gelmektedir. Geçmişten geleceğe uzanan medeniyet yolunda tarihin bilinmesi ve tarihin değer aktarımı işlevinin önemsenmesi millet bilincinin oluşmasında ve milli kimliğin kazandırılmasında son derece önemlidir (Güneş, 2017, s. 4). Birey Türk tarihi hakkında bilgi edinmekle mevcut varlığının temel kaynaklarını öğrenir ve bu bilgi ile kendisine intikal eden mirasın anlamını kavrayarak, milli şahsiyetini ve kimliğini inşa eder (Vurgun, 2016, s. 111). Avrupa'da milli kimliğin inşası amacıyla tarih eğitimi okullarda güçlü bir araç olarak kullanılmaya başlamıştır (Ersanlı, 2006, s. 23). Din, toplumsal kültür içerisinde yer bulan dini ritüel ve törenlerin etkisiyle ulusal kimliğin muhafazasında önemli işlevler gerçekleştirmektedir (Güneş, 2017, s. 83) çalışmaları ile benzerlik göstermektedir.

Sosyal bilgiler öğretmen adaylarının millî kimlik algısı üzerinde en fazla etkili olan unsur ve millî kimlik oluşumunda en fazla etkili olan kurum karşılaştırması incelendiğinde katılımcıların; millî kimlik algısı üzerinde en fazla etkili olan unsur nedir sorusuna cevap verenlerin; \%62.5'i aile \%24.8'i okul \%6.7'si sivil toplum kuruluşları ve \%6.0'sı ise yayınlardan millî kimliği kazandığını belirtmiştir.

Bu sonuçlara göre; ailenin millî kimlik kazanmada en önemli kurum olduğu görülmektedir. Aileden sonra ise okul millî kimlik kazanımındaki ikinci sırada gelen kurumdur. Bu sonuç; kimlik ilk olarak aile ortamında şekillenir (Güleç, 1992, s. 14). Ailede gelişen informal süreç yoluyla toplumu tanıma ve kendini ait hissetme başlar (Karasu Avcl, 2016, s. 10). Kimlik duygumuz, geçmişe uzanan kökleri gerektirir ve bu kökler de öncelikle ailede bulunur (Tosh, 2013, s. 1) çalışmaları ile benzerlik göstermektedir.

\section{Öneriler}

Araştırma sonuçlarına göre, katılımcılar millî kimliğin tarih ve din unsurlarını diğer unsurlardan daha önemli bulduklarını belirtmişlerdir. Sosyal bilgiler lisans programında ve derslerinde millî kimliğin coğrafya, kültür ve dil unsurlarına daha fazla yer verilmesi gerektiği önerilmektedir. 
Katılımcıların yaklaşık 2/3'ü millî kimliği kazandıkları kurum olarak aileyi belirtmiştir. Ailede millî kimlik aktarımı ve kazanımını daha detaylı incelemek için araştırmalar yapılabilir.

Ayrıca okulda da millî kimlik aktarımı ve kazanımının daha iyi nasıl yapılabileceği konusunda da çalışmalar yapılabilir.

Sosyal bilgiler öğretmen adayları üzerinde yapılan bu çalışmanın, millî kimlik unsurlarını içeren diğer öğretmenlik alanlarında da yapılması önerilmektedir.

Sosyal bilgiler dersleri ve öğretmenleri tarafından ortaokul öğrencilerine millî kimliğin aktarılması hedeflenmektedir. Sosyal bilgiler dersinin ve öğretmen adaylarının, ortaokul öğrencilerinin millî kimlik algılarına etkisinin incelenmesi için benzer çalışmaların ortaokul öğrencileri düzeyinde de yapılması önerilmektedir.

Bu araştırmada nicel bir veri toplama aracı kullanılmıştır. Dolayısıyla var olan durum tespit edilip betimlenmeye çalışılmıştır. Millî kimlik algı durumlarının daha detaylı ve derinlemesine bir şekilde ele alınması, bireylerdeki millî kimliğin neden, niçin ve nasıl oluştuğunun tespitleri için nitel araştırmalar yapılması önerilmektedir.

\section{Kaynakça}

Bilgin, N. (1995). Kolektif kimlik. İstanbul: Sistem.

Bilgin, N. (2007). Kimlik inşası. İzmir: Aşina.

Büyüköztürk, Ş., Kılıı̧ E., Akgün, Ö. E., Karadeniz, Ş. \& Demirel, F. (2012). Bilimsel araştırma yöntemleri. Ankara: Pegem A.

Cihad, S. B. C. (2019). Türkmen öğrencilerin millî kimlik algılarının incelenmesi. Yayımlanmamış

Doktora Tezi. Gazi Üniversitesi Eğitim Bilimleri Enstitüsü, Ankara.

Creswell, W. J. (2014). Araştırma deseni nitel, nicel ve karma yöntem yaklaşımları. (S. B. Demir ve M. Bursal. Çev.) içinde (s. 155-182). Ankara: Eğiten kitap. (s.155-182).

Çalık, M. (2009). Millî kimlik milliyet milliyetçilik. Ankara: Cedit.

Çavdarcı, M. (2002). Türkiye'de Sosyal Değerlerin Aşınması ve Kültür Sömürgeciliği. Yayımlanmamış Yüksek Lisans Tezi, Süleyman Demirel Üniversitesi Sosyal Bilimler Enstitüsü, Isparta.

Çeçen, A. (2007). Türkiye cumhuriyeti ulus devleti. Ankara: Fark.

Dağı, Z. (2002). Kimlik, milliyetçilik ve dış politika: Rusya'nın dönüşümü. İstanbul: Boyut.

Doğan, K. (2008). Cumhuriyet dönemi kimlik inşası. Yayımlanmamış Doktora Tezi, Sakaryaüniversitesi Sosyal Bilimler Enstitüsü, Sakarya.

Ersanlı, B. (2006). İktidar ve tarih, turkiye'de "resmi tarih" tezinin oluşumu (1929-1937). İstanbul: Illetişim.

Esgin, A. (2014). Sosyalleşme. M. Ç. Özdemir (Ed.), Eğitim sosyolojisi içinde Ankara: Pegem.

Gelişli, Y. (2014). The development study of national identity perception scale. InternationalJournal on New Trends in Education and Their Implications. 4(5), 1-11.

Güleç, C. (1992). Türkiye'de kültürel kimlik krizi. Ankara: V yayınları. 
Güneş, H. (2017). 9. Sınıf Tarih Dersi “ilk Türk Devletleri” Ünitesine Illişkin Öğrencilerde Türklük Ve Millî Kimlik Kavramlarının Oluşumunun İncelenmesi. Yayımlanmamış Yüksek Lisans tezi, Cumhuriyet üniversitesi Eğitim bilimleri enstitüsü, Sivas.

Güvenç, B. (2008). Türk kimliği kültür tarihinin kaynakları. İstanbul: Boyut.

Karasar, N. (2014). Bilimsel araştırma yöntemi. Ankara: Nobel.

Karasu Avcı, E. (2016). Toplumsal Kimliğin Oluşumunda Sosyal Bilgiler Dersinin Rolünün Incelenmesi: Sosyal Bilgiler Öğretim Programları (1924-2010).Yayımlanmamış Doktora tezi, Kastamonu Üniversitesi Sosyal Bilimler Enstitüsü, Kastamonu.

Kodaman, B. (2004). Millî kimlik ve küreselleşme-dünyalılaşma. Türk Yurdu Dergisi, 200(24),29-34.

Köktürk, M. (2016). Millet ve milliyetçilik. İstanbul: Ötüken.

Kösoğlu, N. (2015). Türk kimliği ve Türk dünyası. İstanbul: Ötüken.

Sözen, E. (1999). Demir kafesten plastiğe kimliklerimiz sekülerleşme sürecinde kimliklerin inşası. İstanbul: Birey.

Şen, F. Y. (2004). Globalleşme sürecinde milliyetçilik trendleri ve ulus devlet. Ankara: Yargı.

Tabur, E. (2014). Öğrencilerde millî kimlik kavramı ve T.C. inkılâp tarihi ve Atatürkçülük dersinin millî kimlik kazanımına etkisi. Yayımlanmamış Yüksek Lisans Tezi. Abant İzzet Baysal Üniversitesi Eğitim Bilimleri Enstitüsü, Bolu.

Tekinalp, Ş. (2005). Küreselleşen dünyanın bunalımı: çok kültürlülük. Journal of Istanbul Kultur University. 1, 75-87.

Tosh, J. (2013). Tarihin peşinde. (Ö. Arıkan, Çev.). İstanbul: Tarih Vakfı Yurt.

Turan, M. (2009). 1950 ile 1960 yılları arası ortaokul tarih dersi kitaplarında yer alan millî kimlik kavramının içerik analizi. Yayımlanmamış Yüksek Lisans Tezi, Gazi Üniversitesi Eğitim Bilimleri Enstitüsü, Ankara.

Türkbağ, U. A. (2003). Kimlik, hukuk ve adalet sorunu. Doğu Batı Dergisi, 23, 209-219.

Türkdoğan, O. (2007). Türk toplumunun kültürel dinamikleri. İstanbul: Kum saati.

Vatandaş, C. (2004). Ulusal kimlik; Türk ulusçuluğunun doğuşu. İstanbul: Açılım.

Vurgun, A. (2016). Milli tarih nedir? İstanbul: Yeni İnsan. 